\title{
Differential effects of erufosine on proliferation, wound healing and apoptosis in colorectal cancer cell lines
}

\author{
FERDA KALEAĞASIOĞLU and MARTIN R. BERGER \\ Toxicology and Chemotherapy Unit, German Cancer Research Center, D-69120 Heidelberg, Germany
}

Received October 22, 2013; Accepted November 21, 2013

DOI: $10.3892 /$ or.2013.2942

\begin{abstract}
The alkylphosphocholine, erucylphospho- $N, N$, $N$-trimethylpropanolamine (erufosine), has demonstrated anticancer effects in various cell lines, including leukemia, multiple myeloma, bladder, breast and oral squamous cell carcinoma cells. The purpose of the present study was to investigate its antiproliferative, antimigratory and pro-apoptotic effects in colorectal cancer cell lines, SW480 and CC531. The antiproliferative effect was determined by (3-[4,5-dimethylthiazol-2-yl]-2, 5-diphenyltetrazolium bromide) (MTT) dye reduction assay following exposure to erufosine (3.1-100 $\mu \mathrm{M})$ for 24-72 h. The antimigratory effect of erufosine (1.6-6 $\mu \mathrm{M})$ was investigated by a wound healing assay for 12-48 h. Caspase-3/-7 activity was measured to detect apoptotic cell death. Erufosine inhibited cell proliferation in a dose- and time-dependent manner. The $\mathrm{IC}_{50}$ values following $72 \mathrm{~h}$ of incubation were 3.4 and $25.4 \mu \mathrm{M}$ for SW480 and CC531 cells, respectively. Erufosine at concentrations of 50 and $100 \mu \mathrm{M}$ induced caspase-3/-7 activity concentration-dependently in SW480 cells, but only at $100 \mu \mathrm{M}$ in CC531 cells. Incubation of SW480 cells with erufosine $(1.56 \mu \mathrm{M})$ for $48 \mathrm{~h}$ inhibited migration into the scratched area by $54 \%$ as compared to the untreated cells; whereas in CC531 cells, the wound width in the erufosine-treated (1.56-6.25 $\mu \mathrm{M})$ cells following $48 \mathrm{~h}$ was closed 2-fold slower than the rate in the untreated group. Erufosine $(25 \mu \mathrm{M})$ attenuated osteonectin expression and abolished COL1A1 expression in CC531 cells. Erufosine appears to be a promising treatment agent for colorectal cancer. Rat CC531 cells are less sensitive to erufosine than human SW480 cells.
\end{abstract}

\section{Introduction}

Colorectal cancer is among the leading 25 causes of global mortality (1). Age standardized rates for colorectal cancer

Correspondence to: Dr Martin R. Berger, Toxicology and Chemotherapy Unit, German Cancer Research Center, Im Neuenheimer Feld 581, D-69120 Heidelberg, Germany

E-mail: m.berger@dkfz-heidelberg.de

Key words: erufosine, colorectal cancer cell lines, wound healing, osteonectin, collagen incidence and mortality rank fourth as reported by the World Health Organization Globocan Project. Although early detection and/or treatment have improved the outcome substantially, a relatively high number of new cases and deaths are still expected for 2013 (2).

Currently used antineoplastic drugs against colorectal cancer include antimetabolites $(3,4)$, alkylating agents $(5)$ and camptothecin analogs (6). The antimetabolites, 5-fluorouracil (5-FU) and capecitabine, are utilized in various combination regimens. The response rate to $5-\mathrm{FU}$ was shown to increase following leucovorin (LV) modulation but the survival rate remained unchanged. Addition of either oxaliplatin (FOLFOX) (7) or irinotecan (FOLFIRI) (8) to 5-FU and LV combination led to prolongation of progression-free survival (PFS) and higher response rates with an acceptable tolerability profile in patients with metastatic colorectal cancer when used as first-line therapy. Overall response and survival rates by FOLFOX and FOLFIRI regimens are similar (9). Regimens in which the alkylating agent oxaliplatin was added to fluorouracil (FUOX) or capecitabine (CAPOX) also yielded no significant difference between the two study arms, and the median survival rate remained between 18 and 21 months (10). Targeted therapies with monoclonal antibodies against the epidermal growth factor receptor (EGFR) were found to be correlated with prolonged survival rates; however, therapeutic efficacy decreased significantly in patients with K-RAS mutations $(11,12)$. Anti-VEGF agents such as bevacizumab and aflibercept also demonstrated beneficial effects $(13,14)$. Bevacizumab was evaluated in combination with either capecitabine plus oxaliplatin (XELOX) or with FOLFOX in patients with metastatic colorectal cancer. Addition of bevacizumab significantly prolonged PFS; however, overall survival and response rates were not improved (15). Today the prognosis of colorectal cancer is predicted by tumor staging. Overall survival rate in stage IV and recurrent colorectal cancer ranges between 15 and 25 months depending on the combination regimen employed. Therefore, new drugs or combinations are required to improve the prognosis of colorectal cancer.

Alkylphosphocholines (APCs) are a novel class of antineoplastic agents. APCs are structurally related to alkyllysophospholipids (edelfosine and ilmofosine) with the exception of the glycerol backbone, which was deemed unnecessary for cytotoxic activity $(16,17)$. Unlike classical chemotherapeutics, APCs target the cell membrane instead of DNA. At clinically relevant doses, they interfere with phospholipid turnover; hence 
with cell signaling and survival pathways (18). Such distinctive features may facilitate their therapeutic efficacy, and render them potential candidates for combination therapies (19).

The prototype of APCs, hexadecylphosphocholine (miltefosine), did not meet expectations due to low response rates and high gastrointestinal toxicity. Today, miltefosine use is limited to topical treatment of skin metastases and oral leishmaniasis treatment (18). By structural modifications of APCs, many of these pending obstacles could be overcome. The most recent APCs, erucylphosphocholine (ErPC) and its homolog erufosine (erucylphospho- $N, N, N$-trimethylpropanolamine, ErPC3) are quite promising with favorable pharmacokinetic and pharmacodynamic properties. They have significant cytotoxic efficacy but cause less gastrointestinal toxicity. They possess the ability to cross the blood-brain barrier and to accumulate in the brain tissue, which indicates their potential for the treatment of brain tumors (19). Owing to their structure with a 22-carbon chain and a $\omega-9$ cis-double bond, they have reduced myelotoxic and hemolytic effects (20-22) and because of the latter property, the agents are also the first intravenously applicable APCs.

In vitro, the antiproliferative effect of erufosine was demonstrated in various cell lines of human origin such as chronic myeloid leukemia (CML; alone and when combined with imatinib) (23), acute myeloid leukemia (AML) $(24,25)$, chronic lymphocytic leukemia (CLL) (26), multiple myeloma (MM) $(20,27)$, bladder carcinoma (28), breast carcinoma (29) and oral squamous cell carcinoma (30). Bladder carcinoma, AML and multiple myeloma cell lines were more sensitive to erufosine in vitro, and the $\mathrm{IC}_{50}$ values ranged between 4 and $14 \mu \mathrm{M}(25,27,28)$. However, higher $\mathrm{IC}_{50}$ values $(22-41 \mu \mathrm{M})$ were detected in CLL, breast and oral squamous carcinoma cell lines $(26,29,30)$. Erufosine also reduced colony formation in human MM, breast and pancreatic carcinoma cells (22) and inhibited migration in human MM cells (20).

Erufosine induced apoptosis in CLL (26), AML $(24,25)$, acute lymphocytic leukemia (ALL) (31), human glioblastoma (31-33), prostate (34) and oral squamous carcinoma (30) cell lines of human origin. Its cytotoxic effect was decreased considerably by caspase inhibitors $(25,26)$. For this reason, part of its antineoplastic activity was associated with apoptosis (35). Activation of executive procaspase- 3 and cleavage of its substrate poly(ADP-ribose) polymerase (PARP) are well documented time- and concentration-dependent effects of erufosine (24-26,31-34). Erufosine-induced apoptosis was modulated via the JNK 1/2, Raf/MEK/ERK and $\mathrm{PI} 3 \mathrm{~K} / \mathrm{Akt} / \mathrm{mTOR}$ signaling pathways $(25,27,30,34)$.

The antineoplastic effects of APCs on colorectal cancer cell lines have been previously reported (36,37). Miltefosine was more effective in the colon adenocarcinoma cell line, $\mathrm{HT} 29\left(\mathrm{IC}_{50}, 3.1 \mu \mathrm{mol} / \mathrm{l}\right)$ as compared to mammary carcinoma cell lines ( $\left.\mathrm{IC}_{50}, 29.4-69.9 \mu \mathrm{mol} / \mathrm{l}\right)(36)$. Against this colorectal cell line, miltefosine was more effective when compared to other APC congeners such as octadecenyl-(trans9.10)-phosphocholine, octadecenyl-(cis-9.10)-phosphocholine and octadecylphosphocholine ( $\mathrm{IC}_{50}, 5.8,17.8$ and $4.4 \mu \mathrm{mol} / 1$, respectively) (37). An antineoplastic effect of erufosine in colorectal cancer cell lines has not yet been reported. Therefore, the aim of the present study was to investigate and compare the antiproliferative, antimigratory and pro-apoptotic effects of erufosine in colorectal cell lines of human (SW480) and rat (CC531) origin.

\section{Materials and methods}

Cell culture. The colon adenocarcinoma cell lines, SW480 (human) and CC531 (rat), free of pathogenic contamination, were grown as monolayers in RPMI-1640 medium supplemented with $10 \%$ fetal calf serum (FCS) and L-glutamine $(2 \mathrm{mM})$. The cell lines were maintained in an incubator with a humidified atmosphere $\left(5 \% \mathrm{CO}_{2}\right.$ in air at $\left.37^{\circ} \mathrm{C}\right)$. Cells were passaged two or three times a week to maintain them in a logarithmic growth phase. For isolation and propagation, the medium was discarded, and then the cells were washed with phosphate-buffered saline (PBS), trypsinized ( $0.25 \%$ trypsin/EDTA), pelleted at $1,500 \mathrm{rpm}$ for $5 \mathrm{~min}$ and re-suspended at the desired concentration in RPMI-1640 medium.

Cell proliferation assay. Cell proliferation was assessed by MTT (3-[4,5-dimethylthiazol-2-yl]-2,5-diphenyltetrazolium bromide) dye reduction assay as described by Mosmann, with some modifications (38). In brief, MTT (Sigma, Munich, Germany) solution (10 mg/ml in PBS) was added (10 $\mu \mathrm{l} / \mathrm{well})$. Plates were further incubated for $3 \mathrm{~h}$, and following removal of the medium, the formazan crystals were dissolved by the addition of $100 \mu \mathrm{l}$ solvent $(0.04 \mathrm{~N} \mathrm{HCl}$ acid in 2-propanol) per well and then by thoroughly mixing. Optical density was measured at a $540-\mathrm{nm}$ wavelength $(690 \mathrm{~nm}$ reference wavelength) using an ELISA plate reader (Anthos Mikrosysteme $\mathrm{GmbH}$, Krefeld, Germany). Cell doubling time (DT) was calculated by using the Patterson formula: $\mathrm{Td}=\mathrm{T} \times \lg 2 /(\operatorname{lgN} 2-\operatorname{lgN} 1)$ where $\mathrm{Td}$ is the doubling time (in hours), $\mathrm{N}$ is the number of cells and $\mathrm{T}$ is the time for cell growth from N1 to N2. Cell growth rates (in hours) were calculated by the following formula: Growth rate $(\mu)=\ln \left(\mathrm{N}_{2} / \mathrm{N}_{1}\right) / \mathrm{T}_{2}-\mathrm{T}_{1}$.

The optimal cell number to be seeded was determined before assessment of the antiproliferative effects of erufosine in both cell lines. For the growth curves, SW480 and CC531 cells were seeded in 96-well microplates at final concentrations of $2 \times 10^{3}, 4 \times 10^{3}, 8 \times 10^{3}$ cells/well and $2 \times 10^{3}, 4 \times 10^{3}$ cells/well, respectively. For exposure to erufosine, cells were seeded into 96-well microplates $\left(2 \times 10^{3}\right.$ cells $/ 100 \mu 1$ medium/well for SW480 and $4 \times 10^{3}$ cells/100 $\mu 1$ medium/well for CC531) and incubated with increasing concentrations $(3.1,6.3,12.5$, $17.7,25,35.4,50,70.7$ and $100 \mu \mathrm{M}$ ) for 24,48 and $72 \mathrm{~h}$. Cell survival rates were expressed as the percentage of untreated controls at 24,48 and $72 \mathrm{~h}$. $\mathrm{IC}_{50}$ was calculated by the equation of logarithmic regression trendline.

In vitro wound healing (scratch) assay. SW480 and CC531 cells were seeded $(10,000$ cells/well) in 24-well plates and allowed to attach to the surface under standard incubation conditions for $24 \mathrm{~h}$. After $24 \mathrm{~h}$, the confluent cell monolayers were scratched in a straight line using a $200-\mu$ l sterile plastic pipette tip, as previously described (39). The cells were then carefully rinsed with culture medium to remove free-floating cells and debris. Then, erufosine was added at final concentrations of 1.56, 3.125 and $6.5 \mu \mathrm{M} / \mathrm{well}$, and the effect on wound healing was monitored. Scratch zones representative for each 
cell line were photographed at $12,24,36$ and $48 \mathrm{~h}$ by the Axio Observer.Z1 microscope (Carl Zeiss AG, Oberkochen, Germany). Each experiment was conducted in triplicate wells for each concentration of erufosine and the control. AxioVision Rel. 4.8 software was used for the measurements. For SW480 cells, cells that had migrated into the scratched area were counted within a 400x400 $\mu \mathrm{m}$ frame, which was created by the region of interest (ROI) function, enabling to select 3 random regions in the scratched area. For the CC531 cells, the distance between the wound edges was measured. For both cell lines, three random measurements were made per photographed sample at $12 \mathrm{~h}$, which was used as baseline. Both cell lines were studied in parallel, and the duration of the microscopic procedure was kept the same to exclude environmental condition-related differences in wound healing responses.

Caspase assay. Caspase-3/-7 enzymatic activity was measured by Apo-ONE Homogeneous Caspase-3/7 assay (G7792 Promega, Germany), according to the manufacturer's instructions. Briefly, SW480 and CC531 cells were seeded at a final concentration of 10,000 cells/well in a black 96-well plate, $24 \mathrm{~h}$ before drug treatment. Erufosine was added to the wells at final concentrations of 50 and $100 \mu \mathrm{M}$ and incubated for $5 \mathrm{~h}$ in an incubator $\left(5 \% \mathrm{CO}_{2} / 95 \% \mathrm{O}_{2}\right.$ at $\left.37^{\circ} \mathrm{C}\right)$. A standard assay (96-well, $200 \mu \mathrm{l}$ final reaction volume) was conducted in triplicate involving three groups: blank [caspase reagent $(\mathrm{CR})+$ cell culture medium without cells], negative control $(\mathrm{CR}+$ vehicletreated cell culture) and assay ( $\mathrm{CR}+$ treated cell culture). The contents of wells were gently mixed using a plate-shaker at $300-500 \mathrm{rpm}$ for $5 \mathrm{~h}$ at room temperature $\left(25^{\circ} \mathrm{C}\right)$. Immediately after this process, the fluorescence of each well was measured using a spectrofluorometer at an excitation wavelength range of $485 \pm 20 \mathrm{~nm}$ and an emission wavelength range of $530 \pm 25 \mathrm{~nm}$. Blank values were subtracted from the experimental values to obtain the relative fluorescence units (RFUs).

Gene expression analysis. CC531 cells were seeded at a density of 200,000 cells in 25-ml flasks. After $24 \mathrm{~h}$, the medium was changed and the cells were exposed to erufosine $(12,5$ and $25 \mu \mathrm{M})$ for $48 \mathrm{~h}$. For osteonectin expression, an additional experiment was conducted as follows. CC531 cells were seeded at a density of 400,000 cells/well of a 6 -well plate. Medium was changed after $24 \mathrm{~h}$, and the cells were incubated with erufosine $(25 \mu \mathrm{M})$ for 24 and $48 \mathrm{~h}$. Then, the cells were harvested, and the cell pellets were stored at $-20^{\circ} \mathrm{C}$ until RNA isolation. Total RNA was isolated from CC531 cell pellets by the RNeasy Mini kit (Qiagen GmBH, Hilden, Germany) and then first strand cDNA was synthesized by Thermo Scientific Maxima reverse transcriptase kit (Thermo Scientific GmbH, Schwerte, Germany) according to the manufacturer's protocols. Gene expression was studied by basic PCR protocol (Invitrogen $\mathrm{GmbH}$, Karlsruhe, Germany). The following rat primers were used: ON, gagtttggcagctcagagga (left) and tctgct tctgagatgggtca (right); $\gamma$-tubulin, gatggcagtgacagcctagag (left) and gccgttccaagaggtagga (right); COL1A1, catgttcagctttgtgga cct (left) and gcagctgacttcagggatgt (right); COL1A2, cctggctct cgaggtgaac (left) and caatgcccagaggaccag (right). Each gene expression experiment was repeated twice. $\gamma$-tubulin served as the housekeeping gene. PCR products were analyzed by poly- acrylamide gel electrophoresis (PAGE). Thermo Scientific pUC19 DNA/Mspl (Hpall) Marker was used for sizing and approximate quantification of the PCR products (Thermo Scientific). Lanes were framed automatically and corresponding band intensities were calculated by Quantity One 1-D Analysis software (Bio-Rad Laboratories Inc., Hercules, CA, USA). For normalization, the band intensity value of the target gene was divided by the band intensity of the housekeeping gene $\gamma$-tubulin.

Statistical analysis. The data are presented as mean values $\pm \mathrm{SD}$. The survival rates between the treatment groups were compared by ANOVA Dunnett's test. Statistical differences in wound healing and caspase assays were calculated by one way, single factor ANOVA test. P-values $\leq 0.05$ were considered to indicate statistically significant results.

\section{Results}

Growth curves of SW480 and CC531 cells. SW480 cells had a doubling time of $22.5 \pm 2.8,20.0 \pm 4.1$ and $24.3 \pm 9.3 \mathrm{~h}$ and growth rates of $0.031,0.035$ and $0.031 \mathrm{~h}^{-1}$ when seeded at a density of $2 \times 10^{3}, 4 \times 10^{3}$ and $8 \times 10^{3}$ cells/well, respectively. CC531 cells had a doubling time of $18.8 \pm 1.0$ and $22.6 \pm 1.4 \mathrm{~h}$ and growth rates of 0.037 and $0.031 \mathrm{~h}^{-1}$ when seeded at a density of $2 \times 10^{3}$ and $4 \times 10^{3}$ cells/well, respectively.

Antiproliferative effect of erufosine on SW480 cells. Survival rates of the SW480 cells following exposure to erufosine are shown in Fig. 1A. Erufosine exerted a concentration- and time-dependent antiproliferative effect. This effect was observed after $24 \mathrm{~h}$ with concentrations $\geq 12.5 \mu \mathrm{M}$. However, a significant difference from the control group was found at all concentrations at 48 and $72 \mathrm{~h}$. The antiproliferative effect of erufosine significantly increased with longer exposure times at all concentrations. The $\mathrm{IC}_{50}$ values of erufosine in the SW480 cell line were $30.3,9.9$ and $3.4 \mu \mathrm{M}$ following 24,48 , and $72 \mathrm{~h}$ of incubation, respectively. The relevant regression equations and their corresponding $\mathrm{R}^{2}$ values are provided in Fig. $1 \mathrm{~B}$. In the dose-response curve, a steep decline in the survival rate was observed at high erufosine concentrations (70.7 and $100 \mu \mathrm{M})$, preceded by a gradual decrease at low concentrations (Fig. 1A). The shoulder width and the amplitude became smaller in a time-dependent manner.

Antiproliferative effect of erufosine on CC531 cells. Survival rates of the CC531 cells following exposure to erufosine are shown in Fig. 2A. An antiproliferative effect was observed at concentrations $\geq 25 \mu \mathrm{M}$ after $24 \mathrm{~h}(\mathrm{P}=0.003)$ and $48 \mathrm{~h}$ $(\mathrm{P}<0.0001)$ of incubation. After $72 \mathrm{~h}$, no significant cytotoxic effect was demonstrated at the concentrations of $3.125,6.25$ and $12.5 \mu \mathrm{M}(\mathrm{P}>0.05)$. At the effective concentrations, the survival rates decreased significantly as the incubation time was prolonged. The $\mathrm{IC}_{50}$ values of erufosine in the CC531 cell line were 34.9, 29.7 and $25.4 \mu \mathrm{M}$ following 24, 48 and $72 \mathrm{~h}$ of incubation, respectively. The relevant regression equations and their corresponding $\mathrm{R}^{2}$ values are provided in Fig. $2 \mathrm{~B}$. In the dose-response curve, a steep decrease in the survival rate was observed at high erufosine concentrations (70.7 and $100 \mu \mathrm{M})$, preceded by a gradual decrease at low concentrations 
A
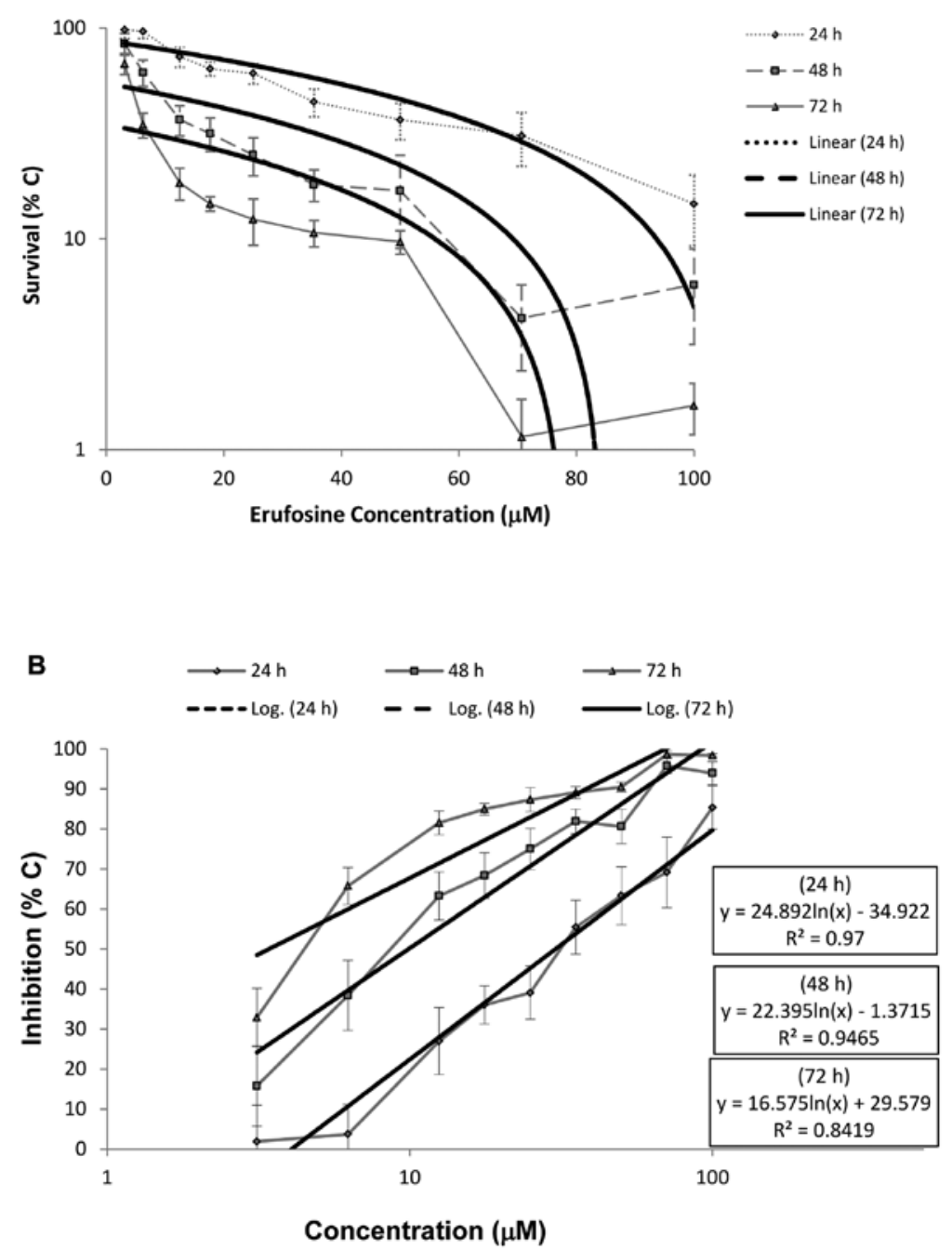

Figure 1. Survival curves of SW480 cells following exposure to increasing erufosine concentrations (3.13-100 $\mu \mathrm{M})$. The values represent the means \pm SD. The survival rates between the treatment groups were compared by ANOVA Dunnett's test, and P-values $\leq 0.05$ were considered to indicate statistically significant results. (A) Survival rates of erufosine-treated cells are indicated as the percentage of untreated cells. The antiproliferative effect (treated vs. untreated) was significant at $\geq 12.5 \mu \mathrm{M}$ concentrations at $24 \mathrm{~h}$, but at all concentrations following 48 and $72 \mathrm{~h}(\mathrm{P}<0.05)$. (B) Inhibition of proliferation in erufosine-treated cells is indicated as the percentage of the untreated control. Logarithmic regression equations and corresponding $\mathrm{R}^{2}$ values are provided in the boxes. $\mathrm{IC}_{50}$ values were calculated by logarithmic regression trendline analysis: $\mathrm{IC}_{50}(24 \mathrm{~h})=30.31 \mu \mathrm{M}, \mathrm{IC}_{50}(48 \mathrm{~h})=9.91 \mu \mathrm{M}, \mathrm{IC}_{50}(72 \mathrm{~h})=3.43 \mu \mathrm{M}$.

(Fig. 2A). This shoulder effect was concentration- and timedependent. The amplitude and the width were higher at 48 and $72 \mathrm{~h}$ when compared to the survival curve of the SW480 cells. The shoulder width became smaller after $48 \mathrm{~h}$. There was no significant difference between the survival rates for 70.7 and $100 \mu \mathrm{M}$ after 48 and $72 \mathrm{~h}$. The survival curves after 48 and $72 \mathrm{~h}$ nearly overlapped with each other.

Wound healing assay in SW480 and CC531 cells. The wound healing assay was followed over $48 \mathrm{~h}$ for the low concentrations used in the cytotoxicity assay. Both cell lines displayed different migratory profiles during wound healing. SW480 cells migrated to the scratched area and closed the wound by forming colonies during the 'healing' process. In the CC531 cell culture, the wound edges approached each other to close the 'wound.' Untreated SW480 cells showed a time-dependent ability to close the gap and increasingly more cells migrated into the scratched area (Fig. 3A). This difference in migra- tion was statistically significant at $24(\mathrm{P}=0.003), 36$ and $48 \mathrm{~h}$ $(\mathrm{P}<0.0001)$. In $\mathrm{SW} 480$ cells, erufosine at a concentration of $1.56 \mu \mathrm{M}$ inhibited wound healing, and this effect was significantly different from the control group after $12(\mathrm{P}=0.001), 24$, $(\mathrm{P}=0.007), 36,(\mathrm{P}=0.02)$ and $48 \mathrm{~h}(\mathrm{P}<0.0001)$ (Fig. 3C). This effect observed following erufosine treatment $(1.56 \mu \mathrm{M})$ indicated $53.8 \pm 13.3 \%$ inhibition of wound healing as compared to the control group at $48 \mathrm{~h}$. In the SW480 cells, apoptotic morphological changes were noted at the $6.3 \mu \mathrm{M}$ concentration even after $12 \mathrm{~h}$ of incubation and these signs were also observable, although less distinct, at the $3.1 \mu \mathrm{M}$ concentration. Apoptotic cells lost contact with their neighbors, became rounded and detached from the surface displaying pronounced membrane blebbing. At a concentration of $1.56 \mu \mathrm{M}$, SW480 cells displayed no apparent signs of apoptosis. CC531 cells also had a good capacity to fill the gap (Fig. 3B). In the untreated group, the distance between the two edges of the wound progressively decreased. This decrease became statisti- 

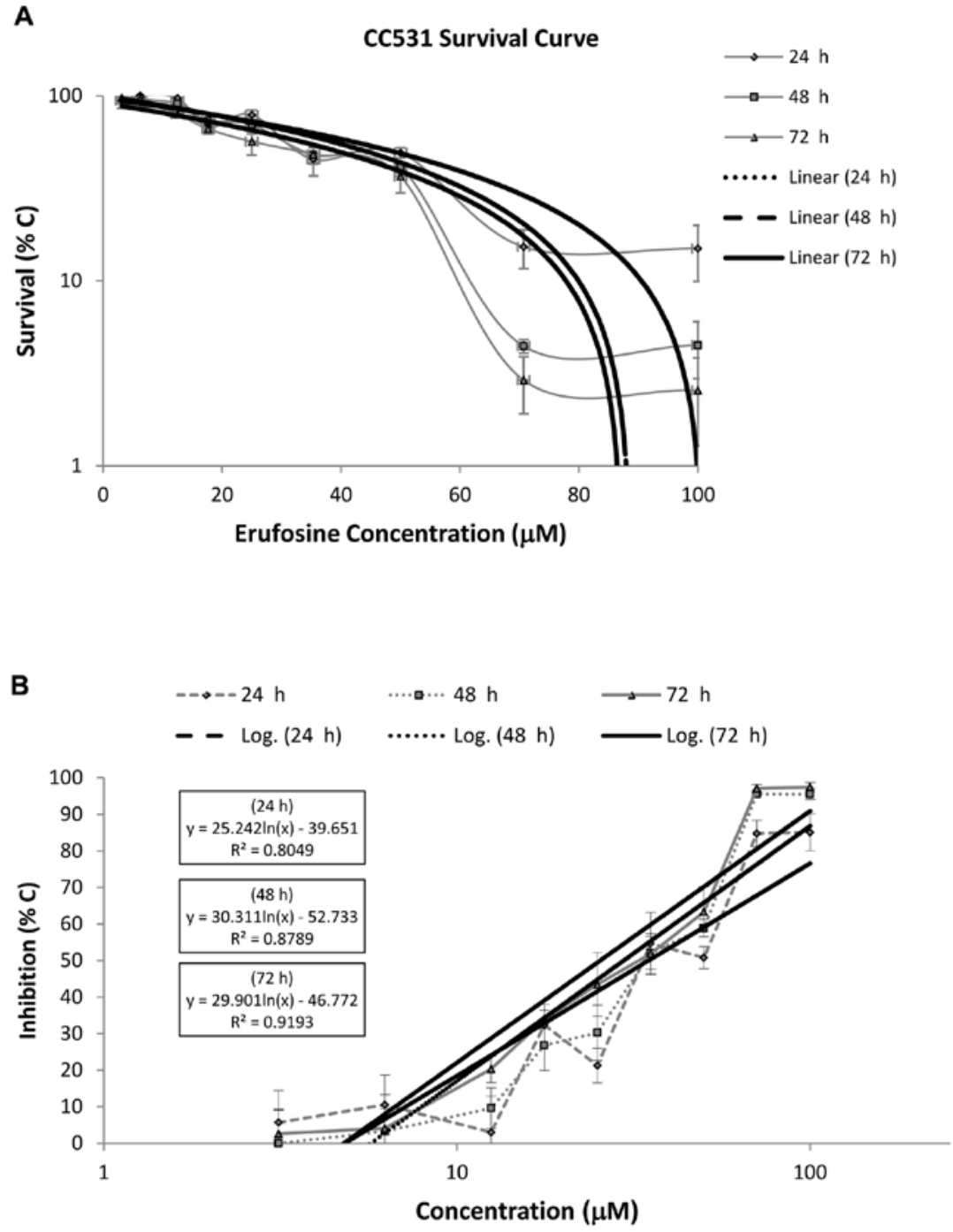

Figure 2. Survival curves of CC531 cells following exposure to increasing erufosine concentrations (3.13-100 $\mu \mathrm{M})$. The values represent the means \pm SD. The survival rates between the treatment groups were compared by ANOVA Dunnett's test, and P-values $\leq 0.05$ were considered to indicate statistically significant results. (A) Survival rates of the erufosine-treated cells are indicated as the percentage of untreated cells. The antiproliferative effect (treated vs. untreated) was significant only at $\geq 25 \mu \mathrm{M}$ concentrations $(\mathrm{P}<0.05)$. (B) Inhibition of proliferation in erufosine-treated cells is indicated as the percentage of untreated control. Logarithmic regression equations and corresponding $\mathrm{R}^{2}$ values are provided in the boxes. $\mathrm{IC}_{50}$ values were calculated by logarithmic regression trendline analysis: $\mathrm{IC}_{50}(24 \mathrm{~h})=34.87 \mu \mathrm{M}, \mathrm{IC}_{50}(48 \mathrm{~h})=29.65 \mu \mathrm{M}, \mathrm{IC}_{50}(72 \mathrm{~h})=25.44 \mu \mathrm{M}$.

cally significant at $36 \mathrm{~h}(\mathrm{P}<0.002)$, and was more pronounced at $48 \mathrm{~h}(\mathrm{P}<0.0001)$, which corresponds to a wound healing of $62.2 \%$. In the CC531 cells, erufosine inhibited wound healing capacity, which became evident by $48 \mathrm{~h}$ at all concentrations tested when compared with their corresponding baseline values (1.56, 3.125 and $6.25 \mu \mathrm{M} ; \mathrm{P}<0.0001)$. As compared to the control following $48 \mathrm{~h}$, the gap widths in the erufosine-treated cells were $183.5 \pm 75.2(\mathrm{P}=0.0025), 207.7 \pm 81.6(\mathrm{P}<0.0001)$ and $221.0 \pm 67.2 \%(\mathrm{P}<0.0001)$ of the untreated cells following treatment with 1.56, 3.125 and $6.25 \mu \mathrm{M}$, respectively (Fig. 3D). Thus, erufosine-treated CC531 cells had an 2 -fold wider wound width after $48 \mathrm{~h}$, as compared to the control group. A significant concentration-dependent effect was observed at erufosine concentrations between 1.56 and $6.25 \mu \mathrm{M}$ at 24 and $36 \mathrm{~h}$, respectively $(\mathrm{P}=0.0002)$. However, at $48 \mathrm{~h}$ this concentration-dependent effect could not be observed any longer between the treatment groups: 1 vs. $3 \mu \mathrm{M}(\mathrm{P}=0.277)$, 1 vs. $6 \mu \mathrm{M}(\mathrm{P}=0.064)$ and 3 vs. $6 \mu \mathrm{M}(\mathrm{P}=0.168)$. No morpho- logical signs of apoptosis were detected in the CC531 cells at test concentrations.

Caspase assay. In both cell lines, erufosine induced caspase-3/-7 enzymatic activity (Fig. 4). In the SW480 cells, erufosine had a concentration-dependent effect on caspase release. The fluorescence readings (RFU) were $851 \pm 18,1686 \pm 55$ and $2093 \pm 144$ for the untreated, 50 and $100 \mu \mathrm{M}$ erufosine-treated groups, respectively. This concentration-dependent response was significantly different from the control group $(\mathrm{P}=0.035$ for $50 \mu \mathrm{M}$ and $\mathrm{P}<0.001$ for $100 \mu \mathrm{M})$ and also between both concentrations $(\mathrm{P}=0.0001)$. In the CC531 cells, RFU values were $1746 \pm 274,2232 \pm 471$ and $15916 \pm 3973$ for the untreated and erufosine (50 and $100 \mu \mathrm{M}$ )-treated groups, respectively. In the CC531 cells, there was no significant difference between the $50 \mu \mathrm{M}$ and the untreated control group, whereas the difference between $100 \mu \mathrm{M}$ and the untreated group was statistically significant $(\mathrm{P}=0.0035)$. 

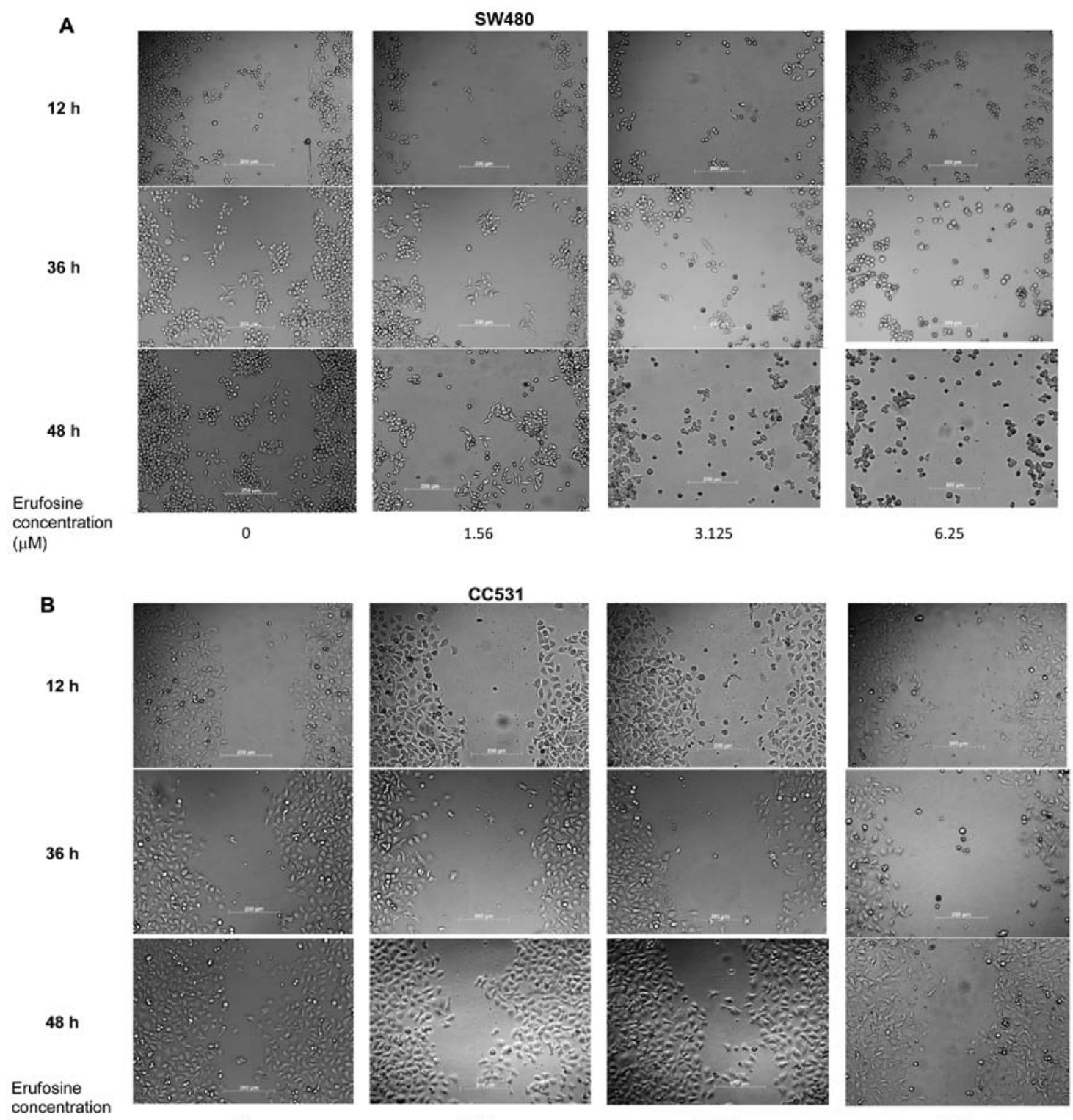

( $\mu \mathrm{M})$

0

1.56

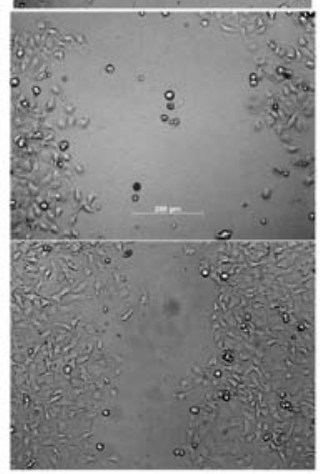

3.125

6.25
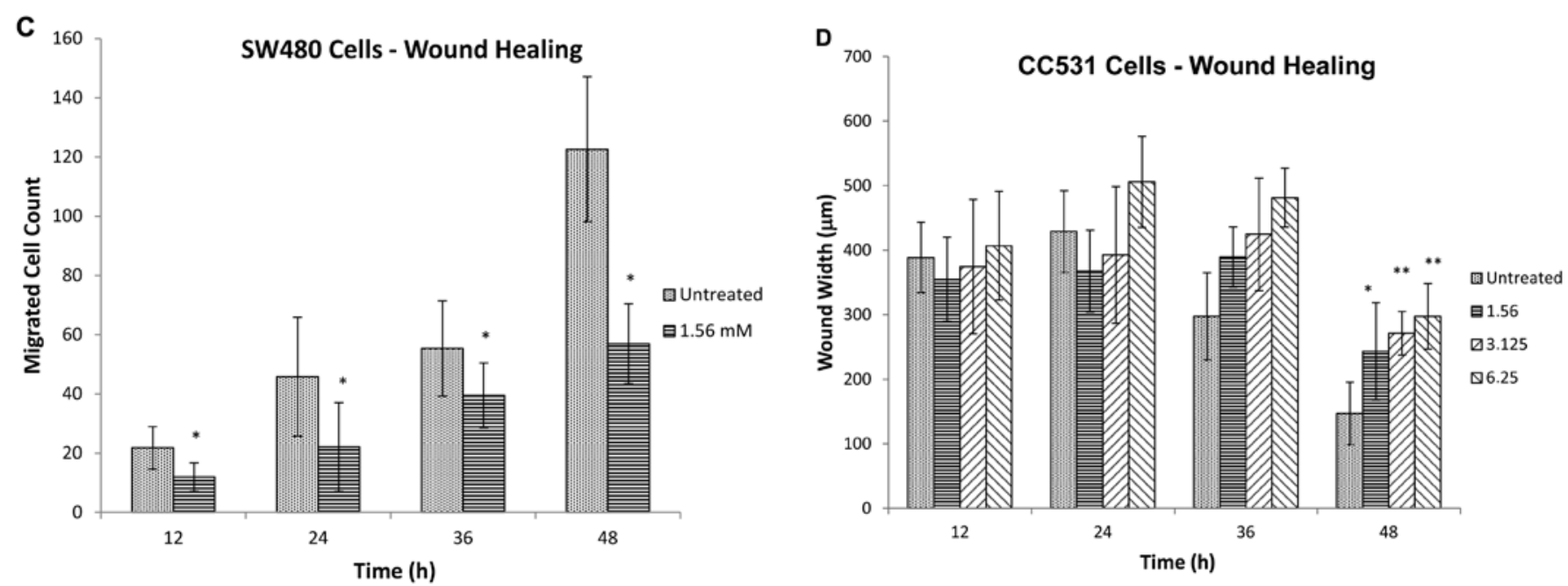

Figure 3. Wound healing responses of colorectal cancer cell lines following exposure to erufosine. AxioVision Rel. 4.8 software was used for the measurements. The values represent the means \pm SD $(n=9)$. Statistical significance was calculated by one way, single factor ANOVA test, and P-values $\leq 0.05$ were considered to indicate statistically significant results. (A) SW480 and (B) CC531 cells were incubated with erufosine (1.56-6.25 $\mu$ M) and photographed at $12,24,36$ and $48 \mathrm{~h}$ by an Axio Observer.Z1 microscope. Magnification in the photomicrographs is $\mathrm{x} 10$. Bars indicate $200 \mu \mathrm{m}$. (C) Erufosine (1.56 $\mu \mathrm{M})$ significantly delayed wound healing in the SW480 cells at 12, 24, 36 and $48 \mathrm{~h}$ when compared to the untreated group (P<0.0001). (D) Erufosine (1.56, 3.125 and $6.25 \mu \mathrm{M})$ significantly delayed wound healing in CC531 cells at $48 \mathrm{~h}$ when compared to the untreated group $\left({ }^{*} \mathrm{P}<0.0025\right.$ untreated vs. $1.56 \mu \mathrm{M},{ }^{* *} \mathrm{P}<0.0001$ untreated vs. 3.125 and $6.25 \mu \mathrm{M})$. 


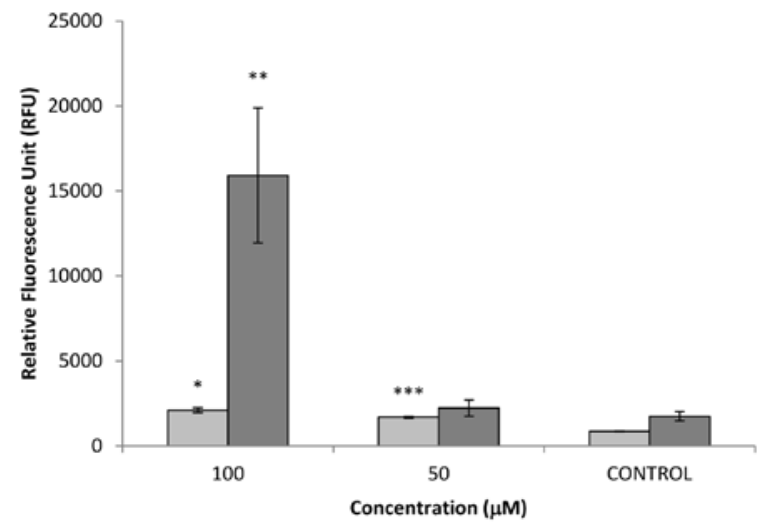

Figure 4. Caspase-3/-7 enzymatic activity in the SW480 and CC531 cells following $5 \mathrm{~h}$ of incubation with erufosine $(50$ and $100 \mu \mathrm{M})$. Spectrofluorometric measurement was conducted at an excitation wavelength range of $485 \pm 20 \mathrm{~nm}$ and an emission wavelength range of $530 \pm 25 \mathrm{~nm}$. Blank values were subtracted from the experimental values to obtain the relative fluorescence units (RFUs). The values represent the means \pm SD $(n=3)$. Statistical significance was calculated by one way, single factor ANOVA test, and P-values $\leq 0.05$ were considered to indicate statistically significant results. ${ }^{*} \mathrm{P}<0.001,{ }^{* *} \mathrm{P}=0.0035$, ${ }^{* * *} \mathrm{P}<0.001$; statistically significant difference for erufosine-treated cells vs. untreated (control) cells.

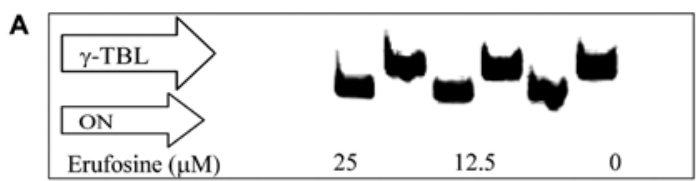

B

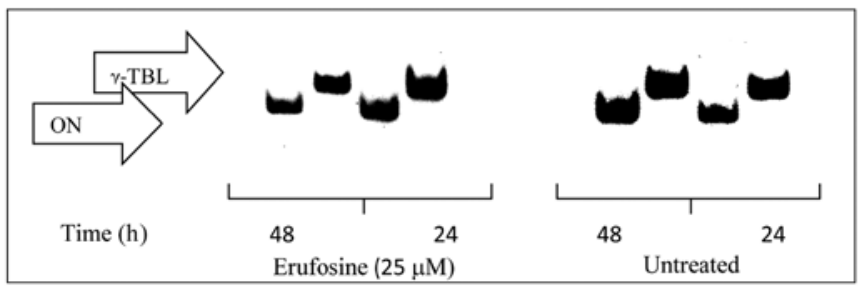

Figure 5. Osteonectin (ON) expression in CC531 cells following exposure to erufosine $(0-25 \mu \mathrm{M})$. Expression patterns were analyzed by RT-PCR and PAGE. $\gamma$-tubulin $(\gamma$-TBL) served as the housekeeping gene. For normalization, the band intensity value of the target gene was divided by the band intensity of $\gamma$-TBL. (A) Osteonectin expression after incubation with erufosine $(12.5$ and $25 \mu \mathrm{M})$ for $48 \mathrm{~h}$. (B) Osteonectin expression after incubation with erufosine $(25 \mu \mathrm{M})$ for 24 and $48 \mathrm{~h}$.

Osteonectin, COL1A1 and A2 expression in CC531 cells. Erufosine $(25 \mu \mathrm{M})$ incubation attenuated osteonectin expression by 12 and $11 \%$ following 24 and $48 \mathrm{~h}$ of incubation (Fig. 5). Erufosine $(25 \mu \mathrm{M})$ abolished COL1A2 expression after $48 \mathrm{~h}$ (Fig. 6) but no change was observed for COL1A1 (Fig. 6).

\section{Discussion}

This is the first report on the activity of erufosine in colorectal cell lines, SW480 and CC531. Our in vitro results showed concentration- and time-dependent antiproliferative effects in both cell lines. After $72 \mathrm{~h}$, similar growth inhibitory effects were observed at a concentration of $100 \mu \mathrm{M}$ in both cell lines, but at lower concentrations, erufosine was significantly more

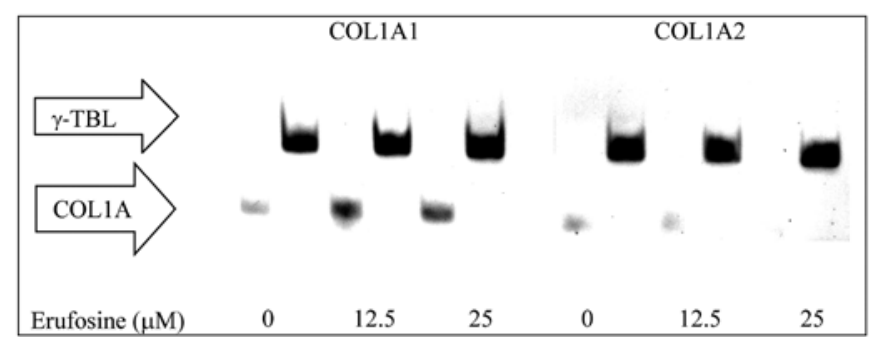

Figure 6. COL1A1 and COL1A2 expression in CC531 cells following exposure to erufosine $(0-25 \mu \mathrm{M})$ for $48 \mathrm{~h}$. Expression patterns were analyzed by RT-PCR and PAGE. $\gamma$-tubulin ( $\gamma$-TBL) served as the housekeeping gene. For normalization, the band intensity value of the target gene was divided by the band intensity of $\gamma$-TBL.

effective in SW480 cells. The $\mathrm{IC}_{50}$ value decreased progressively with prolonged incubation times in the SW480 cells but such a decline was not observed in the CC531 cells. Following $72 \mathrm{~h}$ of exposure to erufosine, the $\mathrm{IC}_{50}$ value for CC531 cells was nearly 4-fold higher than that of the SW480 cells. An antiproliferative effect of erufosine has been demonstrated in various human-derived cell lines, as outlined in Fig. 7. When compared to other types of human cancers, erufosine exhibits marked antiproliferative activity in SW480 cells, similar to bladder carcinoma and several (OPM-2 and RPMI-8226) MM cell lines. However, erufosine failed to show the same degree of efficacy in CC531 cells, and its efficacy in SW480 cells was only comparable to oral squamous carcinoma and CLL cells. CC531 cells were also shown to be less sensitive to the alkylating agent melphalan, when compared to SW480 cells (40).

For SW480 and CC531 cells, shoulder-type survival curves were demonstrated (Fig. 3A and 4A). Survival rates declined gradually between 3.1 and $50 \mu \mathrm{M}$ but a steep decrease was observed at high concentrations (70.7 and $100 \mu \mathrm{M})$. Shoulders on survival curves have been explained by two models. In a multi-hit target model, shoulders are due to the need to hit more than one target for cell-killing and zero or non-zero initial slopes at low doses become exponential as higher concentrations are reached. In the repair model, shoulders indicate that cells can proficiently repair the damage (41). If the repair process is saturated with some damage left, the dying process is initiated (42). Our results demonstrated marked differences between shoulder-type survivals in both cell lines. The shoulder had a higher magnitude and a broader width in CC531 cells. The shoulder magnitudes and final slopes of the survival curves may be altered by dose-dependent DNA repair mechanisms and/or interdependence of lethal/mutational responses (41). Cells display differential capacities to accumulate and repair sublethal damage. For example, the survival curve of HeLa cells had a small initial shoulder and a modest dose-rate effect. However, Chinese hamster cells displayed a broad shoulder and a large dose-rate effect. Such a difference was suggested to indicate the dominance of apoptotic cell death in HeLa cells (43). The shoulders on the survival curves of CC531 and SW480 cells (Figs. 1A and 2A) may indicate the synthesis of anti-apoptotic or pro-survival factor(s), which can help to repair erufosine-induced cellular damage(s). For example, high expression of the inhibitor of apoptosis protein (IAP) family (survivin, XIAP and other members) has been 


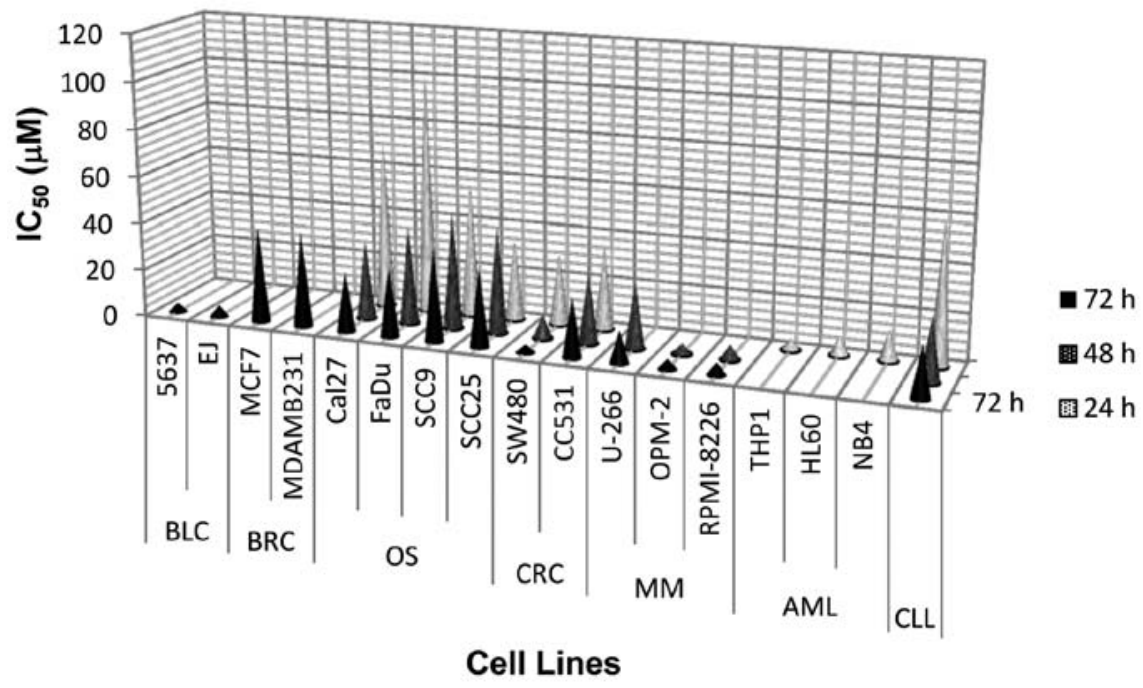

Figure 7. Comparison of $\mathrm{IC}_{50}$ values $(\mu \mathrm{M})$ of erufosine in various cell lines, following incubation for 24,48 or $72 \mathrm{~h}$. Our results for SW480 and CC531 cells are represented under CRC (colorectal carcinoma). BLC, bladder carcinoma [Konstantinov et al (28)]; BRC, breast carcinoma [Dineva et al (29)]; OS, oral squamous carcinoma [Kapoor et al (30)]; MM, multiple myeloma [Yosifov et al (20)]; AML, acute myeloid leukemia [Martelli et al (25)]; CLL, chronic lymphocytic leukemia [Königs et al (26)].

associated with colon carcinogenesis and resistance to chemotherapeutic agents (44). Other pro-survival factors such as insulin-like growth factor binding proteins, IGFBP3 and 7, CXCL5 and sirtuin 1 were also reported for colorectal cancer cell lines (45-47). Anti-apoptotic or pro-survival factor(s) against erufosine-induced cytotoxicity remain to be identified.

Cell survival depends on the balance between antiapoptotic [Ras-Raf-MAPK/ERK and phosphatidylinositol 3'-kinase (PI3K)/Akt] and pro-apoptotic (SAPK/JNK) signaling mechanisms. Inhibition of survival pathways is a well-documented effect of APCs (19). Accordingly, the pro-apoptotic effect of erufosine has been demonstrated in various cell lines (24-27,30-35). Erufosine-induced apoptosis was correlated with hypo-phosphorylation (activation) of the retinoblastoma $(\mathrm{Rb})$ protein, which inhibits $\mathrm{Abl}$ and JNK kinases as well as E2F transcription factors $(35,48)$. The mitochondrial death pathway is another mechanism in erufosine-induced apoptosis $(31-33,49)$. Caspase-3 was also suggested as one of the major determinants of erufosineinduced apoptosis (50). A concentration-dependent activation of caspase- 3 and cleavage of the caspase- 3 substrate PARP were detected in prostate cancer (PC3 and LNCaP) cells in response to erufosine treatment $(12.5-25 \mu \mathrm{M})(34)$. In another study, erufosine $(10 \mu \mathrm{M})$ treatment for $6-12 \mathrm{~h}$ resulted in depletion of procaspases and induced PARP cleavage (92\%) in MM cells (OPM-2) (27). In freshly isolated CLL cells, erufosine (1-100 $\mu \mathrm{M})$ cleaved PARP totally after $24 \mathrm{~h}$ in a concentration-dependent manner and a pan-caspase inhibitor completely abrogated apoptosis (26). Erufosine at concentrations of 30 and $50 \mu \mathrm{M}$ enhanced caspase-3/-7 activity and cleavage of PARP in a concentration-dependent manner in oral squamous carcinoma cells (30). Our results showing enhanced caspase-3/-7 activity in both cell lines confirm these previous reports. Erufosine-induced caspase3/-7 activity was concentration-dependent in SW480 cells, but was observed only at a high $(100 \mu \mathrm{M})$ concentration in CC531 cells. Additionally, control caspase-3/-7 activity was higher (2-fold) in the CC531 than this activity in the SW480 cells, and this difference grew markedly (8-fold) following erufosine exposure $(100 \mu \mathrm{M})$. However, erufosine $(100 \mu \mathrm{M}$, $72 \mathrm{~h}$ ) eventually exhibited the same antiproliferative effect in both cell lines. Caspase activation is not necessarily related to apoptosis in colorectal cancer cells (51). Beyond cell death, caspases are involved in many functions such as cellular formation and differentiation. Cytokines, tyr protein kinases, Ser/Thr protein kinases, protein phosphatases and G-proteins have been shown to be substrates of caspases. For this reason, caspase activation and cleavage of their substrates cannot be solely interpreted as irreversible processing of programmed cell death (52). Furthermore, caspase activation is not the unique determinant in programmed cell death. Caspaseindependent cell death programs include autophagy, mitotic catastrophe, slow cell death and paraptosis (53). For example, APC-induced cell death was shown to be BCL-XL-sensitive and caspase-independent in human malignant glioma cells (54). According to our results, apoptosis is unlikely to be the major pathway for programmed cell death in CC531 cells at test concentrations, as supported by its characteristic survival curve (broad shoulder, high amplitude and steep slope) and lack of apoptotic signs during the wound healing assay (43).

APCs were shown to inhibit migration of human retinal pigment epithelial (RPE) cells by $>90 \%$ in a concentrationdependent manner. Inhibition of migration was correlated with carbon chain length of the APC. For APCs longer than 20 carbon atoms (>C20), the $\mathrm{IC}_{50}$ value of $\mathrm{RPE}$ cell migration ranged between 0.1 and $1 \mu \mathrm{M}$, but increased to $10 \mu \mathrm{M}$ for a chain length of $18 \mathrm{C}(55)$. Our wound healing assay showed that the $\mathrm{IC}_{50}$ of erufosine $(22 \mathrm{C})$ ranged from 1.56 to $3.1 \mu \mathrm{M}$ in both cell lines. Retarding effects of antineoplastic drugs on wound healing are well known, but they vary in their efficacy to inhibit collagen synthesis. Only the DNA alkylating agent cisplatin strongly and specifically inhibited collagen synthesis in colon fibroblasts (56). Similarly, the alkylating agent ET-743 was shown to reduce COL1A1 mRNA levels up to $80 \%$ in 
scleroderma fibroblasts (57). We studied the effect of erufosine on COL1A1 and COL1A2 expression in CC531 cells, which was more prone to the retarding effect of erufosine on wound healing. Our results demonstrated that erufosine $(25 \mu \mathrm{M})$ reduced the COL1A2 band intensity to an undetectable level but did not have any influence on COL1A1 expression. Osteonectin, a member of the 'secreted protein acidic and rich in cysteine' (SPARC) family of proteins is also involved in wound repair. SPARC silencing in human tendon fibroblasts did not interfere with cell proliferation but displayed an antifibrotic effect by reducing collagen I expression (58). Our results showed that erufosine $(25 \mu \mathrm{M})$ caused a slight $(12 \%)$ reduction in osteonectin expression.

In light of our findings, erufosine appears to be a promising chemotherapeutic agent in colorectal cancer. We observed marked differences in the antiproliferative, delayed wound healing and apoptotic effects between SW480 and CC531 cells. CC531, an immortalized cell line from a DMH-induced adenocarcinoma in rats, was less sensitive to erufosine than SW480 cells of human origin. Since a single human colorectal cancer cell line is inadequate to reflect the molecular heterogeneity of clinical colorectal tumors (59), future research should include various cell lines of different origins to further elucidate their survival mechanisms against erufosine.

\section{References}

1. Lozano R, Naghavi M, Foreman K, et al: Global and regional mortality from 235 causes of death for 20 age groups in 1990 and 2010: a systematic analysis for the Global Burden of Disease Study 2010. Lancet 380: 2095-2128, 2012.

2. Siegel R, Naishadham D and Jemal A: Cancer Statistics 2013. CA Cancer J Clin 63: 11-30, 2013.

3. Buyse M, Thirion P, Carlson RW, Burzykowski T, Molenberghs G and Piedbois P: Relation between tumour response to first-line chemotherapy and survival in advanced colorectal cancer: a meta-analysis. Lancet 356: 373-378, 2000.

4. Hoff PM, Ansari R, Batist G, et al: Comparison of oral capecitabine versus intravenous fluorouracil plus leucovorin as first-line treatment in 605 patients with metastatic colorectal cancer: results of a randomized phase III study. J Clin Oncol 19: 2282-2292, 2001.

5. Porschen R, Arkenau HT, Kubicka S, et al: Phase III study of capecitabine plus oxaliplatin compared with fluorouracil and leucovorin plus oxaliplatin in metastatic colorectal cancer: a final report of the AIO Colorectal Study Group. J Clin Oncol 25 4217-4223, 2007.

6. Fuchs CS, Marshall J, Mitchell E, et al: Randomized, controlled trial of irinotecan plus infusional, bolus, or oral fluoropyrimidines in first-line treatment of metastatic colorectal cancer: results from the BICC-C Study. J Clin Oncol 25: 4779-4786, 2007.

7. de Gramont A, Figer A, Seymour M, et al: Leucovorin and fluorouracil with or without oxaliplatin as first-line treatment in advanced colorectal cancer. J Clin Oncol 18: 2938-2947, 2000 .

8. Saltz LB, Cox JV, Blanke C, et al: Irinotecan plus fluorouracil and leucovorin for metastatic colorectal cancer. N Engl J Med 343: 905-914, 2000.

9. Colucci G, Gebbia V, Paoletti G, et al: Phase III randomized trial of FOLFIRI versus FOLFOX4 in the treatment of advanced colorectal cancer: a multicenter study of the Gruppo Oncologico Dell'Italia Meridionale. J Clin Oncol 23: 4866-4875, 2005.

10. Díaz-Rubio E, Tabernero J, Gómez-España A, et al: Phase III study of capecitabine plus oxaliplatin compared with continuousinfusion fluorouracil plus oxaliplatin as first-line therapy in metastatic colorectal cancer: final report of the Spanish Cooperative Group for the Treatment of Digestive Tumors Trial. J Clin Oncol 25: 4224-4230, 2007.

11. Tol J, Koopman M, Cats A, et al: Chemotherapy, bevacizumab, and cetuximab in metastatic colorectal cancer. N Engl J Med 360: 563-572, 2009.
12. Van Cutsem E, Peeters M, Siena S, et al: Open-label phase III trial of panitumumab plus best supportive care compared with best supportive care alone in patients with chemotherapy-refractory metastatic colorectal cancer. J Clin Oncol 25: 1658-1664, 2007.

13. Kubicka S, Greil R, André T, et al: Bevacizumab plus chemotherapy continued beyond first progression in patients with metastatic colorectal cancer previously treated with bevacizumab plus chemotherapy: ML18147 study KRAS subgroup findings. Ann Oncol 24: 2342-2349, 2013.

14. Van Cutsem E, Tabernero J, Lakomy R, et al: Addition of aflibercept to fluorouracil, leucovorin, and irinotecan improves survival in a phase III randomized trial in patients with metastatic colorectal cancer previously treated with an oxaliplatin-based regimen. J Clin Oncol 30: 3499-3506, 2012.

15. Saltz LB, Clarke S, Díaz-Rubio E, et al: Bevacizumab in combination with oxaliplatin-based chemotherapy as first-line therapy in metastatic colorectal cancer: a randomized phase III study. J Clin Oncol 26: 2013-2019, 2008.

16. Hilgard P, Klenner T, Stekar J and Unger C: Alkylphosphocholines: a new class of membrane-active anticancer agents. Cancer Chemother Pharmacol 32: 90-95, 1993.

17. Berkovic D: Cytotoxic ether-phospholipid analogues. Gen Pharmacol 31: 511-517, 1998.

18. Vink SR, van Blitterswijk WJ, Schellens JHM and Verheij M: Rationale and clinical application of alkylphospholipid analogues in combination with radiotherapy. Cancer Treat Rev 33: 191-202, 2007.

19. Van Blitterswijk WJ and Verheij M: Anticancer mechanisms and clinical application of alkylphospholipids. Biochim Biophys Acta 1831: 663-674, 2013.

20. Yosifov DY, Todorov PT, Zaharieva MM, Georgiev KD, Pilicheva BA, Konstantinov SM and Berger MR: Erucylphospho$\mathrm{N}, \mathrm{N}, \mathrm{N}$-trimethylpropylammonium (erufosine) is a potential antimyeloma drug devoid of myelotoxicity. Cancer Chemother Pharmacol 67: 13-25, 2011.

21. Georgieva MC, Konstantinov SM, Topashka-Ancheva M and Berger MR: Combination effects of alkylphosphocholines and gemcitabine in malignant and normal hematopoietic cells. Cancer Lett 182: 163-174, 2002.

22. Bagley RG, Kurtzberg L, Rouleau C, Yao M and Teicher BA: Erufosine, an alkylphosphocholine, with differential toxicity to human cancer cells and bone marrow cells. Cancer Chemother Pharmacol 68: 1537-1546, 2011.

23. Zaharieva MM, Konstantinov SM, Pilicheva B, Karaivanova M and Berger MR: Erufosine - a membrane targeting antineoplastic agent with signal transduction modulating effects. Ann NY Acad Sci 1095: 182-192, 2007.

24. Fiegl M, Lindner LH, Juergens M, Eibl H, Hiddemann W and Braess J: Erufosine, a novel alkylphosphocholine, in acute myeloid leukemia: single activity and combination with other antileukemic drugs. Cancer Chemother Pharmacol 62: 321-329, 2008.

25. Martelli AM, Papa V, Tazzari PL, et al: Erucylphosphohomocholine, the first intravenously applicable alkylphosphocholine, is cytotoxic to acute myelogenous leukemia cells through JNKand PP2A-dependent mechanisms. Leukemia 24: 687-698, 2010.

26. Königs SK, Pallascha CP, Lindnerb LH, et al: Erufosine, a novel alkylphosphocholine, induces apoptosis in CLL through a caspase-dependent pathway. Leuk Res 34: 1064-1069, 2010.

27. Yosifov DY, Reufsteck C, Konstantinov SM and Berger MR: Interleukin-6, osteopontin and Raf/MEK/ERK signaling modulate the sensitivity of human myeloma cells to alkylphosphocholines. Leuk Res 36: 764-772, 2012.

28. Konstantinov SM and Berger MR: Human urinary bladder carcinoma cell lines respond to treatment with alkylphosphocholines. Cancer Lett 144: 153-160, 1999.

29. Dineva IK, Zaharieva MM, Konstantinov SM, Eibl H and Berger MR: Erufosine suppresses breast cancer in vitro and in vivo for its activity on PI3K, c-Raf and Akt proteins. J Cancer Res Clin Oncol 138: 1909-1917, 2012.

30. Kapoor V, Zaharieva MM, Das SN and Berger MR: Erufosine simultaneously induces apoptosis and autophagy by modulating the Akt-mTOR signaling pathway in oral squamous cell carcinoma. Cancer Lett 319: 39-48, 2012.

31. Lemeshko VV and Kugler W: Synergistic inhibition of mitochondrial respiration by anticancer agent erucylphosphohomocholine and cyclosporin A. J Biol Chem 282: 37303-37307, 2007. 
32. Rübel A, Handrick R, Lindner LH, et al: The membrane targeted apoptosis modulators erucylphosphocholine and erucylphosphohomocholine increase the radiation response of human glioblastoma cell lines in vitro. Radiat Oncol 1: 6, 2006.

33. Veenman L, Alten J, Linnemannstöns K, et al: Potential involvement of F0F1-ATP(synth)ase and reactive oxygen species in apoptosis induction by the antineoplastic agent erucylphosphohomocholine in glioblastoma cell lines: a mechanism for induction of apoptosis via the $18 \mathrm{kDa}$ mitochondrial translocator protein Apoptosis 15: 753-768, 2010.

34. Rudner J, Ruiner CE, Handrick R, Eibl HJ, Belka C and Jendrossek V: The Akt-inhibitor erufosine induces apoptotic cell death in prostate cancer cells and increases the short term effects of ionizing radiation. Radiat Oncol 5: 108, 2010.

35. Berger MR, Tsoneva I, Konstantinov SM and Eibl H: Induction of apoptosis by erucylphospho- $N, N, N$-trimethylammonium is associated with changes in signal molecule expression and location. Ann NY Acad Sci 1010: 307-310, 2003.

36. Sobottka SB and Berger MR: Assessment of antineoplastic agents by MTT assay: partial underestimation of antiproliferative properties. Cancer Chemother Pharmacol 30: 385-393, 1992.

37. Sobottka SB, Berger MR and Eibl H: Structure-activity relationships of four anti-cancer alkylphosphocholine derivatives in vitro and in vivo. Int J Cancer 53: 418-425, 1993.

38. Mosmann T: Rapid colorimetric assay for cellular growth and survival: application to proliferation and cytotoxicity assays. J Immunol Methods 65: 55-63, 1983.

39. Liang CC, Park AY and Guan JL: In vitro scratch assay: a convenient and inexpensive method or analysis of cell migration in vitro. Nat Protoc 2: 329-333, 2007.

40. Rothbarth J, Koevoets C, Tollenaar RA, Tilby MJ, van de Velde CJ, Mulder, GJ and Kuppen PJ: Immunohistochemical detection of melphalan-DNA adducts in colon cancer cells in vitro and human colorectal liver tumours in vivo. Biochem Pharmacol 67: 1771-1778, 2004.

41. Haynes RH, Eckardt F and Kunz BA: The DNA damage-repair hypothesis in radiation biology: comparison with classical hit theory. Br J Cancer 49: 81-90, 1984

42. Orr JS: Concepts, problems and the role of modifying agents in the relationship between recovery of cells' survival ability and mechanisms of repair of radiation lesions. Br J Cancer (Suppl) 49: 1-6, 1984.

43. Hall EJ and Brenner DJ: Radiobiology of low- and high-doserate brachytherapy. In: Technical Basis of Radiation Therapy. 4th edition. Levitt SH, Purdy JA, Perez CA and Vijayakumar S (eds). Springer Verlag, Berlin, pp291-307, 2008.

44. Miura K, Fujibuchi W, Ishida K, et al: Inhibitor of apoptosis protein family as diagnostic markers and therapeutic targets of colorectal cancer. Surg Today 41: 175-182, 2011.

45. Georges RB, Adwan H, Hamdi H, Hielscher T, Linnemann U and Berger MR: The insulin-like growth factor binding proteins 3 and 7 are associated with colorectal cancer and liver metastasis. Cancer Biol Ther 12: 69-79, 2011.
46. Kawamura M, Toiyama Y, Tanaka K, et al: CXCL5, a promoter of cell proliferation, migration and invasion, is a novel serum prognostic marker in patients with colorectal cancer. Eur J Cancer 48: 2244-2251, 2012.

47. Kabra N, Li Z, Chen L, et al: SirT1 is an inhibitor of proliferation and tumor formation in colon cancer. J Biol Chem 284: 18210-18217, 2009.

48. Yosifov DY, Dineva IK, Zaharieva MM, Konstantinov SM and Berger MR: The expression level of the tumor suppressor retinoblastoma protein $(\mathrm{Rb})$ influences the antileukemic efficacy of erucylphospho-N,N,N-trimethylpropylammonium (ErPC3). Cancer Biol Ther 6: 930-935, 2007.

49. DeGregori J: The Rb network. J Cell Sci 117: 3411-3413, 2004.

50. Kugler W, Buchholz F, Köhler F, Eibl H, Lakomek M and Erdlenbruch B: Downregulation of Apaf-1 and caspase-3 by RNA interference in human glioma cells: consequences for erucylphosphocholine-induced apoptosis. Apoptosis 10: 1163-1174, 2005.

51. Yang SY, Bolvin C, Sales KM, Fuller B, Seifalian AM and Winslet MC: IGF-I activates caspases $3 / 7,8$ and 9 but does not induce cell death in colorectal cancer cells. BMC Cancer 9: 158, 2009.

52. Nhan TQ, Liles WC and Schwartz SM: Physiological functions of caspases beyond cell death. Am J Pathol 169: 729-737, 2006.

53. Bröker LE, Kruyt FAE and Giaccone G: Cell death independent of caspases: a review. Clin Cancer Res 11: 3155-3162, 2005.

54. Naumann U, Wischhusen J, Weit S, Rieger J Wolburg H, Massing U and Weller M: Alkylphosphocholine-induced glioma cell death is BCL-XL-sensitive, caspase-independent and characterized by massive cytoplasmic vacuole formation. Cell Death Differ 11: 1326-1341, 2004.

55. Eibl, KH, Kook D, Priglinger S, Haritoglou C, Yu A, Kampik A and Welge-Lussen U: Inhibition of human retinal pigment epithelial cell attachment, spreading, and migration by alkylphosphocholines. Invest Ophthalmol Vis Sci 47: 364-370, 2006.

56. Hendriks T, Martens MF, Huyben CM and Wobbes T: Inhibition of basal and TGFJ-induced fibroblast collagen synthesis by antineoplastic agents. Implications for wound healing. Br J Cancer 67: 545-550, 1993 .

57. Louneva N, Saitta B, Herrick DJ and Jimenez SA: Transcriptional inhibition of type I collagen gene expression in scleroderma fibroblasts by the antineoplastic drug ecteinascidin 743. J Biol Chem 278: 40400-40407, 2003.

58. Seet LF, Su R, Toh LZ and Wong TT: In vitro analyses of the antifibrotic effect of SPARC silencing in human Tenon's fibroblasts: comparisons with mitomycin C. J Cell Mol Med 16: 1245-1259, 2012.

59. Auman JT and McLeod HL: Colorectal cancer cell lines lack the molecular heterogeneity of clinical colorectal tumors. Clin Colorectal Cancer 9: 40-47, 2010. 